\title{
ANALISIS FRAMING PEMBERITAAN KEMATIAN QASSEM SOLEIMANI DI MEDIA ONLINE HIDAYATULLAH.COM PERIODE JANUARI 2020
}

\author{
Nafisah Zahra, Rachmat Kriyantono, Bambang Dwi Prasetyo \\ Program Studi S2 Ilmu Komunikasi FISIP Universitas Brawijaya \\ Jl. Veteran, Ketawanggede, Lowokwaru, Kota Malang \\ nafisahzahra310@gmail.com
}

\begin{abstract}
This study aims to find out how Hidayatullah.com online media constructs news about the death of Qassem Soleimani. The killing of Soleimani carried out by the United States at Baghdad International Airport, Iraq, on January 3, 2020 by an airstrike. This attack heightened the tension between Iran and the United States. This study uses qualitative methods and Robert Entman's framing analysis. The research data are 5 news texts published by Hidayatullah.com during January 2020 which reported about Soleimani's death. This research focuses on the choice of words in reporting about Soleimani which can form certain framing. Based on the analysis that has conducted, there is an emphasis on the figure of Soleimani as someone who played a role in conflicts in Middle Eastern countries, such as Iraq and Syria. Besides highlighting Soleimani's figure as the cause of Middle East conflict, the 5 articles also emphasize the concerns of various parties over a further conflict between Iran and the United States as the result of Soleimani's murder.
\end{abstract}

Key Words: Qassem Soleimani, framing analysis, Middle East conflict

\begin{abstract}
Abstrak
Penelitian ini bertujuan untuk mengetahui bagaimana media online Hidayatullah.com mengkonstruksi berita tentang kematian Qassem Soleimani. Pembunuhan terhadap Soleimani terjadi melalui serangan udara yang dilakukan oleh Amerika Serikat di Bandara Internasional Baghdad, Irak, pada tanggal 3 Januari 2020. Serangan ini merupakan puncak ketegangan antara Iran dan Amerika Serikat. Penelitian ini menggunakan metode kualitatif dan analisis framing Robert Entman. Data penelitian merupakan 5 teks berita yang dimuat di Hidayatullah.com yang memberitakan tentang kematian Soleimani selama bulan Januari 2020. Penelitian ini berfokus pada pemilihan kata-kata dalam pemberitaan mengenai Soleimani yang dapat membentuk framing tertentu. Berdasarkan analisis framing yang dilakukan, terdapat penonjolan sosok Soleimani sebagai seseorang yang berperan dalam konflik di negara-negara Timur Tengah, seperti Irak dan Suriah. Selain penonjolan sosok Soleimani tersebut, dalam 5 artikel tersebut juga ditekankan mengenai kekhawatiran berbagai pihak atas konflik lebih lanjut antara Iran dan Amerika Serikat sebagai dampak dari pembunuhan Soleimani.
\end{abstract}

Kata kunci: Qassem Soleimani, analisis framing, konflik Timur Tengah 


\section{PENDAHULUAN}

Qassem Soleimani merupakan seorang jenderal Iran yang menjadi komandan bagi Pasukan Quds Korps Garda Revolusi Islam. Soleimani terbunuh pada tanggal 3 Januari 2020 sekitar pukul 01:00 waktu setempat oleh tembakan rudal dari pesawat tak berawak Amerika yang menargetkan mobil yang dikendarainya di dekat Bandara Internasional Baghdad. Muncul berbagai spekulasi bahwa pembunuhan ini memicu Perang Dunia III dikarenakan Qassem Soleimani merupakan salah satu sosok yang sangat berpengaruh di Timur Tengah. Oleh sebab itu, peristiwa pembunuhan Soleimani ini banyak diberitakan di berbagai media berita di seluruh dunia, tidak terkecuali di Indonesia. Salah satu media berita di Indonesia yang memberitakan peristiwa ini adalah media online Islam Hidayatullah.com .

Setiap media berita tidak dapat lepas dari bingkai realitas dalam memuat pemberitaan (Musyaffa, 2017). Hal tersebut dikarenakan setiap media memiliki kebijakannya masing-masing yang mempengaruhi proses penulisan berita. Setiap media memiliki caranya sendiri dalam menunjukkan bahasa penulisan maupun aspek-aspek dari sudut pandang wartawan yang dianggap penting dan perlu untuk dimuat dalam berita (Elmasry, 2009). Oleh sebab itu dalam setiap berita akan ada aspek-aspek yang ditonjolkan. Pemilihan informasi mana yang ditonjolkan dan disembunyikan dapat berbeda antar satu media dengan media yang lain.

Pernyataan di atas mengasumsikan bahwa Hidayatullah.com memiliki sudut pandang tersendiri yang dapat berbeda dengan media lainnya dalam memberitakan kematian Qassem Soleimani. Tujuan dari penelitian ini adalah untuk mengetahui bagaimana Hidayatullah.com mengkonstruksi berita tentang Soleimani.
Sedangkan dari sisi teoritis, penelitian ini memiliki manfaat untuk mengetahui bagaimana media berita di Indonesia, dalam konteks penelitian ini yaitu media online Hidayatullah.com, dalam memposisikan Soleimani dalam sudut pandang tertentu. Secara praktis, penelitian ini diharapkan dapat menjadi pertimbangan bagi praktisi media dalam memberitakan konflik Timur Tengah.

Hadirnya media online menyebabkan penyebaran berbagai peristiwa dan berita di seluruh dunia menjadi sangat cepat. Sama halnya dengan media berita konvensional, informasi-informasi yang disajikan oleh media online disajikan sedemikian rupa dengan menggunakan pilihan kalimat-kalimat tertentu yang dapat menarik minat pembaca (Margianto \& Syaefullah, 2012). Penggunaan kata atau bahasa yang tepat pada artikel berita, membuat berita dapat mudah dimengerti oleh pembaca. Selain itu, berdasarkan Papacharissi \& de Fatima Oliveira (2008), penggunaan kata atau bahasa yang tepat dalam penulisan berita, akan semakin menekankan makna pada pesan yang akan disampaikan.

Pemilihan bahasa penulisan dalam pemberitaan erat hubungannya dengan cara pandang yang digunakan oleh media massa ketika menyeleksi isu dan menonjolkan aspek-aspek berita mana saja yang akan dimuat (Elmasry, 2009). Untuk meneliti bagaimana media memilih untuk menonjolkan aspek-aspek tertentu dalam pemberitaan, maka penulis menggunakan metode analisis framing.

Metode analisis framing merupakan salah satu bentuk metode analisis media. Framing merupakan bentuk penyajian 
realitas dengan cara tidak mengingkari kebenaran tentang suatu peristiwa secara total (Kriyantono, 2014:255). Kebenaran dibelokkan secara halus dengan memberikan penonjolan atau penekanan pada aspekaspek tertentu (Damayanti, et.al., 2016). Analisis framing digunakan untuk mengkaji pembingkaian realitas pada pemberitaan. Pembingkaian yang dilakukan oleh media merupakan proses konstruksi. Pada proses pembingkaian berita, realitas dimaknai dan direkonstruksi dengan cara tertentu. Menurut Al Nahed (2015), dengan melakukan framing maka diharapkan hanya aspek-aspek tertentu saja yang lebih bermakna, lebih diperhatikan, lebih dianggap penting, dan lebih mengena di benak khalayak.

Dalam konteks penelitian ini maka pemberitaan kematian Qassem Soleimani di media online Hidayatullah.com tentunya juga tidak dapat lepas dari framing. Hidayatullah.com merupakan situs penyedia konten berita, kajian Islam, opini keislaman, berita foto, berita video, opini tokoh, dan lain-lain. Berdasarkan penelitian yang dilakukan oleh Rizqiyah (2016), peristiwaperistiwa internasional yang menyentuh emosi umat Islam termasuk menjadi fokus pemberitaan media online Hidayatullah.com. Contoh peristiwa tersebut misalnya adalah penyerangan zionis Israel ke Gaza (Palestina).

Dalam hubungannya dengan penelitian ini, selama bulan Januari 2020, media online Hidayatullah.com turut memberitakan kematian Qassem Soleimani. Media online Hidayatullah.com merupakan media online yang memiliki komitmen menyajikan informasi dan berita seputar dunia Islam (Rizqiyah, 2016). Qassem
Soleimani merupakan perwira militer senior di Iran yang memiliki posisi sebagai komandan Pasukan Quds pada Pasukan Pengawal Revolusi Islam (IRGC). Pasukan Quds merupakan sebuah divisi yang bertanggung jawab untuk operasi ekstrateritorial Iran (Ostovar, 2016). Pasukan ini terlibat secara langsung dan tidak langsung di wilayah Afghanistan, Libanon, dan Yaman. Pasukan Quds memberikan pelatihan kepada ribuan pasukan di beberapa kelompok dan organisasi yang berbeda seperti Hezbollah Lebanon (milisi Syiah Lebanon), milisi Syiah di Irak, Houthi di Yaman, dan Fatemiyoun (milisi Syiah Afghanistan) dan Zeinabiyoun (milisi Syiah Pakistan) di Suriah (Dareini, 2020). Hal inilah yang menyebabkan Soleimani cukup memiliki pengaruh di Timur Tengah, khususnya di Irak dan Suriah.

Di sisi lain, dalam sebuah penelitian yang dilakukan oleh Pohan (2017) dan Rizqiyah (2016), Hidayatullah.com memiliki visi dan misi sebagai media perekat berbagai mazhab di Indonesia. Berdasarkan penelitian Rizqiyah (2016), Hidayatullah.com memiliki misi untuk menjadi media yang mengedepankan informasi yang berimbang. Hidayatullah.com tidak ingin dianggap hanya milik satu golongan, sehingga media ini berusaha untuk memberitakan berbagai lapisan Islam di Indonesia yang beraliran Ahlus Sunnah (Pohan, 2017). Hal ini selaras dengan penelitian yang dilakukan Rizqiyah (2016), bahwa salah satu misi Hidayatullah.com adalah mengokohkan akidah Ahlus Sunnah, dan membentenginya dari gerakan akidah sesat. Hidayatullah.com tidak memberitakan aliran Islam yang 
dianggap sesat, misalnya Syiah dan Ahmadiyah (Pohan, 2017).

Qassem Soleimani merupakan sosok yang membantu milisi Kurdi dan Syiah di Irak dalam melawan ISIS pada tahun 20142015 (Ostovar, 2016). Masih dikutip dari Ostovar (2016), Soleimani dianggap sosok yang paling sigap dalam menghadapi musuh-musuh Iran di medan perang. Pemimpin tertinggi Iran, Ayatollah Ali Khamenei, bahkan menyebut Soleimani sebagai "martir yang hidup" dan menempatkannya dalam jajaran pahlawan Syiah dan Iran. Dalam konteks penelitian ini, terdapat asumsi bahwa Hidayatullah.com memiliki framing tertentu kepada Soleimani, karena Soleimani merupakan seorang Syiah dan perannya dalam membantu milisi Syiah di Irak. Dalam visi dan misi Hidayatullah.com, terdapat pernyataan bahwa Syiah merupakan aliran sesat yang tidak akan diberitakan di medianya.

Dalam menganalisis pemberitaan mengenai kematian Qassem Soleimani, penulis memilih model analisis framing Robert N. Entman. Model analisis framing Entman memberikan fokus pada seleksi isu dan penonjolan aspek (Papacharissi \& de Fatima Oliveira, 2008). Seleksi isu memiliki kaitan dengan pemilihan fakta. Dalam proses pemilihan fakta, terdapat informasi yang dimunculkan, ada juga informasi yang tidak dimunculkan. Menurut Damayanti et.al. (2016) tidak semua informasiinformasi dan aspek-aspek mengenai pemberitaan ditampilkan. Wartawan akan memilih aspek-aspek tertentu dari suatu isu.

\section{METODE PENELITIAN}

Penelitian ini menggunakan metode penelitian kualitatif. Penelitian ini bertujuan untuk menjelaskan suatu fenomena secara mendalam dengan menggunakan pengumpulan data. Penelitian ini menekankan pada kedalaman (kualitas) data, bukan banyaknya data (kuantitas) data (Kriyantono, 2014:57). Menurut Muhammad (2011), metode penelitian kualitatif merupakan prosedur penelitian yang menghasilkan data deskriptif. Bentuk data ini berupa kata-kata tertulis atau lisan dari orang-orang dan perilaku yang diamati.

Penelitian ini menggunakan metode analisis framing untuk menggali data. Analisis framing menurut Kriyantono (2014:256) adalah "analisis untuk mengkaji pembingkaian realitas yang dilakukan media. Framing digunakan media untuk menonjolkan atau memberi penekanan aspek tertentu sesuai kepentingan media". Penelitian berfokus untuk mengetahui bagaimana media online Hidayatullah.com mengkonstruksi berita tentang kematian Qassem Soleimani berdasarkan analisis framing Robert Entman.

Penelitian ini menggunakan teori analisis framing Entman karena teori ini dapat menggambarkan proses seleksi dan penonjolan aspek tertentu dari realitas oleh media (Rachmawati, et.al., 2019). Dalam seleksi dan penonjolan aspek tersebut akan terlihat suatu gambaran atau sebuah masalah yang lebih khusus. Terdapat empat elemen yang digunakan dalam analisis framing Entman, yaitu define problem, diagnose cause, make moral judgement, dan treatment recommendation. Dengan menggunakan analisis framing ini maka akan diketahui secara jelas bagaimana cara media online 
Hidayatullah.com dalam memberikan pemberitaan mengenai kematian Qassem Soleimani.

Sumber data dari penelitian ini adalah lima teks berita yang diambil dari media online Hidayatullah.com. Teks berita yang dipilih adalah teks berita yang berkaitan dengan berita kematian Qassem Soleimani pada periode Januari 2020. Pemilihan periode ini memiliki alasan bahwa bulan Januari 2020 bertepatan dengan pembunuhan Qassem Soleimani, tepatnya pada tanggal 3 Januari 2020.

\section{HASIL DAN PEMBAHASAN}

Peneliti memilih lima teks berita mengenai pembunuhan Qassem Soleimani oleh militer Amerika Serikat pada media online Hidayatullah.com. Lima teks berita tersebut berjudul (1) Serangan AS Tewaskan Komandan Tertinggi Pasukan Pengawal Revolusi Iran Qassem Soleimani; (2) Iran Berjanji Lakukan "Pembalasan" atas Kematian Qassem Soleimani; (3) Puluhan Orang Tewas Terinjak-injak di Pemakaman Soleimani; (4) Iran Tembakkan Lusinan Rudal ke Pangkalan Militer Amerika di Iraq, Washington Siap-siap; (5) Arab Saudi Khawatir akan Menjadi Target Selama Krisis AS-Iran.

Kematian Qassem Soleimani memunculkan reaksi dari rakyat Iran. Reaksi tersebut berupa prosesi pemakaman besarbesaran untuk Soleimani di Iran yang dihadiri oleh jutaan rakyat Iran untuk memberikan penghormatan terakhir mereka kepada Soleimani. Menurut Dareini (2020) prosesi pemakaman tersebut merupakan yang terbesar di Iran setelah proses pemakaman Ayatollah Ruhollah Khomeini, pendiri Republik Islam Iran, pada tahun
1989. Hal ini dipandang sebagai referendum jalanan untuk memberikan dukungan kepada Soleimani (Dareini, 2020)

Pada 8 Januari 2020, Iran menargetkan dua pangkalan militer di Irak yang menampung pasukan Amerika Serikat, yaitu Ain al-Assad di Irak barat dan pangkalan udara al-Taji yang terletak di utara Baghdad, untuk membalas pembunuhan Soleimani (O’Neal, 2020). Pihak Amerika Serikat mengatakan tidak ada yang terbunuh, sementara pihak Iran mengklaim ada korban jiwa. Namun, Pentagon mengakui pada 29 Januari 2020 bahwa 50 tentara AS didiagnosis menderita cedera otak traumatis yang diderita akibat serangan rudal Iran. Hal ini bertentangan dengan pernyataan Trump bahwa tidak ada pasukan yang terluka.

Di sisi lain, sekutu AS seperti Israel dan Arab Saudi ragu-ragu untuk mendukung tindakan AS lebih lanjut di wilayah Timur Tengah. Memang, Trump telah lama menyatakan pendapat bahwa AS tidak bertanggung jawab atas keamanan sekutusekutunya dan telah menunjukkan kurangnya komitmen kepada sekutu-sekutu AS dengan menolak untuk menanggapi serangan 2019 Iran terhadap ladang-ladang minyak Saudi (O’Neal, 2020). Selain itu, IRGC telah mengeluarkan ancaman bahwa sekutu AS yang turut membantu AS dalam melakukan agresi terhadap Iran juga akan menjadi target serangan pembalasan dari Iran. Hal inilah yang memunculkan keraguan bagi sekutu AS untuk memberikan tanggapan mereka terkait pembunuhan Soleimani. Media Hidayatullah.com mencoba menampilkan framing dan peneliti berupaya menggunakan analisis Entman. 
Tabel 1 Analisis Pemberitaan Kematian Qassem Soleimani di Hidayatullah.com

\begin{tabular}{|c|c|c|c|}
\hline Tanggal & Judul Berita & Elemen & Interpretasi \\
\hline \multirow[t]{4}{*}{$\begin{array}{l}3 \\
\text { Januari } \\
2020\end{array}$} & \multirow{4}{*}{$\begin{array}{l}\text { Serangan AS } \\
\text { Tewaskan } \\
\text { Komandan } \\
\text { Tertinggi Pasukan } \\
\text { Pengawal Revolusi } \\
\text { Iran Qassem } \\
\text { Soleimani }\end{array}$} & $\begin{array}{l}\text { Definisi masalah (Define } \\
\text { problems) }\end{array}$ & $\begin{array}{l}\text { Perwira militer senior Iran di } \\
\text { IRGC, Mayor Jenderal } \\
\text { Qassem Soleimani, tewas } \\
\text { karena serangan udara AS }\end{array}$ \\
\hline & & $\begin{array}{l}\text { Sumber masalah (Diagnose } \\
\text { causes) }\end{array}$ & $\begin{array}{l}\text { Seorang milisi pro-Syiah } \\
\text { yang didukung Iran dan } \\
\text { pengunjuk rasa lainnya } \\
\text { menduduki, membakar dan } \\
\text { merusak Kedutaan Besar } \\
\text { Amerika Serikat di } \\
\text { Baghdad. }\end{array}$ \\
\hline & & $\begin{array}{l}\text { Keputusan moral (Moral } \\
\text { judgement) }\end{array}$ & \begin{tabular}{ll} 
Soleimani & \multicolumn{2}{c}{ dipandang } \\
sebagai arsitek dari banyak \\
kegiatan Iran di Timur \\
Tengah
\end{tabular} \\
\hline & & $\begin{array}{l}\text { Penyelesaian } \\
\text { Remedies) }\end{array}$ & $\begin{array}{l}\text { Soleimani adalah salah satu } \\
\text { target paling dicari Israel } \\
\text { dan AS. }\end{array}$ \\
\hline \multirow[t]{4}{*}{$\begin{array}{l}3 \\
\text { Januari } \\
2020\end{array}$} & \multirow{4}{*}{$\begin{array}{l}\text { Iran Berjanji } \\
\text { Lakukan } \\
\text { "Pembalasan" atas } \\
\text { Kematian Qassem } \\
\text { Soleimani }\end{array}$} & $\begin{array}{l}\text { Definisi masalah (Define } \\
\text { problems) }\end{array}$ & $\begin{array}{l}\text { Ketegangan antara Amerika } \\
\text { Serikat dan Iran memuncak } \\
\text { pada Jumat }\end{array}$ \\
\hline & & $\begin{array}{l}\text { Sumber masalah (Diagnose } \\
\text { causes) }\end{array}$ & $\begin{array}{l}\text { Serangan udara AS } \\
\text { membunuh Mayor Jenderal } \\
\text { (Mayjen) Qassem Soleimani }\end{array}$ \\
\hline & & $\begin{array}{l}\begin{array}{l}\text { Keputusan moral (Moral } \\
\text { judgement) }\end{array} \\
\end{array}$ & $\begin{array}{l}\text { Serangan udara beresiko } \\
\text { memicu eskalasi kekerasan } \\
\text { lebih lanjut yang berbahaya }\end{array}$ \\
\hline & & $\begin{array}{l}\text { Penyelesaian } \\
\text { Remedies) }\end{array}$ & $\begin{array}{l}\text { Harga minyak melonjak } \\
\text { lebih dari } 4 \text { persen pada } \\
\text { Jumat setelah berita } \\
\text { kematian Soleimani. }\end{array}$ \\
\hline \multirow[t]{4}{*}{$\begin{array}{l}7 \\
\text { Januari } \\
2020\end{array}$} & \multirow{4}{*}{$\begin{array}{lr}\text { Puluhan } & \text { Orang } \\
\text { Tewas } & \text { Terinjak- } \\
\text { injak } & \text { di } \\
\text { Pemakaman } & \\
\text { Soleimani } & \end{array}$} & $\begin{array}{l}\text { Definisi masalah (Define } \\
\text { problems) }\end{array}$ & $\begin{array}{l}\text { Puluhan orang meninggal } \\
\text { dunia dalam upacara } \\
\text { pemakaman Soleimani }\end{array}$ \\
\hline & & $\begin{array}{l}\text { Sumber masalah (Diagnose } \\
\text { causes) }\end{array}$ & $\begin{array}{l}\text { Terjadi insiden desak- } \\
\text { desakan dalam pemakaman } \\
\text { Soleimani }\end{array}$ \\
\hline & & $\begin{array}{l}\text { Keputusan moral (Moral } \\
\text { judgement) }\end{array}$ & $\begin{array}{l}\text { Prosesi } \\
\text { Soleimani menarik banyak } \\
\text { orang di berbagai kota di } \\
\text { Iran }\end{array}$ \\
\hline & & $\begin{array}{l}\text { Penyelesaian } \\
\text { Remedies) }\end{array}$ & \begin{tabular}{ll} 
Pemakaman & \multicolumn{1}{l}{ tersebut } \\
akhirnya ditunda, tanpa \\
memberikan detail lebih \\
lanjut.
\end{tabular} \\
\hline
\end{tabular}




\begin{tabular}{|c|c|c|c|}
\hline \multirow[t]{4}{*}{$\begin{array}{l}8 \\
\text { Januari } \\
2020\end{array}$} & \multirow{4}{*}{$\begin{array}{l}\text { Iran Tembakkan } \\
\text { Lusinan Rudal ke } \\
\text { Pangkalan Militer } \\
\text { Amerika di Iraq, } \\
\text { Washington Siap- } \\
\text { siap }\end{array}$} & $\begin{array}{l}\text { Definisi masalah (Define } \\
\text { problems) }\end{array}$ & $\begin{array}{l}\text { Iran menembakkan lebih } \\
\text { dari selusin rudal ke pasukan } \\
\text { AS dan pasukan koalisi di } \\
\text { Iraq hari Selasa }\end{array}$ \\
\hline & & $\begin{array}{l}\text { Sumber masalah (Diagnose } \\
\text { causes) }\end{array}$ & $\begin{array}{l}\text { AS membunuh Letnah } \\
\text { Jenderal Qasem Soleimani } \\
\text { dalam serangan udara di ibu } \\
\text { kota Iraq, Baghdad }\end{array}$ \\
\hline & & $\begin{array}{l}\text { Keputusan moral (Moral } \\
\text { judgement) }\end{array}$ & $\begin{array}{lr}\text { Anggota } & \text { parlemen di } \\
\text { Capitol Hill menyatakan } \\
\text { khawatir } & \text { tentang } \\
\text { penyerangan tersebut. }\end{array}$ \\
\hline & & $\begin{array}{l}\text { Penyelesaian } \quad \text { (Suggest } \\
\text { Remedies) }\end{array}$ & $\begin{array}{l}\text { Menurut IRGC, setiap } \\
\text { wilayah yang merupakan } \\
\text { titik awal tindakan agresif } \\
\text { terhadap Iran akan menjadi } \\
\text { sasaran penyerangan }\end{array}$ \\
\hline \multirow[t]{4}{*}{$\begin{array}{l}10 \\
\text { Januari } \\
2020\end{array}$} & \multirow[t]{4}{*}{$\begin{array}{lr}\text { Arab } & \text { Saudi } \\
\text { Khawatir } & \text { akan } \\
\text { Menjadi } & \text { Target } \\
\text { Selama Krisis } & \text { AS- } \\
\text { Iran } & \end{array}$} & $\begin{array}{l}\text { Definisi masalah (Define } \\
\text { problems) }\end{array}$ & $\begin{array}{l}\text { Wakil Menteri Pertahanan } \\
\text { Saudi Khalid Bin Salman } \\
\text { telah berdiskusi dengan } \\
\text { Presiden AS Donald Trump } \\
\text { terkait koordinasi dan upaya } \\
\text { bersama untuk menghadapi } \\
\text { tantangan regional dan } \\
\text { internasional }\end{array}$ \\
\hline & & $\begin{array}{l}\text { Sumber masalah (Diagnose } \\
\text { causes) }\end{array}$ & $\begin{array}{l}\text { Ketegangan politik antara } \\
\text { Iraq dan AS muncul setelah } \\
\text { pembunuhan } \\
\text { Jenderal Iran } \\
\text { Soleimani }\end{array}$ \\
\hline & & $\begin{array}{l}\text { Keputusan moral (Moral } \\
\text { judgement) }\end{array}$ & $\begin{array}{l}\text { Hubungan AS-Saudi sangat } \\
\text { penting untuk melawan } \\
\text { perilaku merusak rezim Iran } \\
\& \text { membawa keseimbangan } \\
\text { di Timur Tengah. }\end{array}$ \\
\hline & & $\begin{array}{l}\text { Penyelesaian } \\
\text { Remedies) }\end{array}$ & $\begin{array}{l}\text { Selama pertemuan dengan } \\
\text { Pompeo, Khalid bin Salman } \\
\text { "meminta untuk menahan } \\
\text { diri". }\end{array}$ \\
\hline
\end{tabular}

Dari hasil temuan data di atas, peneliti menganalisis setiap berita sesuai elemen framing Robert N. Entman. Dengan melakukan analisis framing dengan menggunakan model Entman, maka akan diketahui informasi-informasi dalam berita yang mengalami penonjolan. Dengan melakukan penonjolan informasi dalam berita maka informasi tersebut akan menjadi lebih bermakna, lebih menarik, berarti, atau lebih diingat oleh khalayak (Solihin \& Kurnia, 2017).

Pada berita pertama yang dianalisis yang dimuat pada tanggal 3 Januari 2020 di Hidayatullah.com, fakta pertama yang 
berusaha untuk ditonjolkan adalah mengenai pembunuhan Qassem Soleimani yang dilakukan melalui serangan udara Amerika Serikat. Serangan udara tersebut merupakan serangan yang memang sengaja ditargetkan untuk membunuh Soleimani. Pada berita, pernyataan tersebut ditunjukkan melalui pernyataan dari dua pejabat AS kepada kantor berita Reuters dan juga pernyataan dari Osama bin Javaid dari Al Jazeera.

Sedangkan untuk alasan mengapa pihak AS melancarkan serangan tersebut kepada Soleimani, Hidayatullah.com mendeskripsikannya dengan adanya konflik antara milisi Irak yang didukung oleh Iran dan AS yang terjadi di Irak. Hal ini ditunjukkan dengan pernyataan bahwa terdapat milisi Irak yang didukung oleh Iran dan pengunjuk rasa yang membakar dan merusak Kedutaan Besar Amerika Serikat di Baghdad. Unjuk rasa dan pembakaran tersebut merupakan reaksi dari serangan udara yang dilakukan oleh AS pada malam tahun baru yang menewaskan 25 pasukan PMF atau kelompok Hashd al-Shaabi. Kelompok Hashd al-Shaabi atau PMF merupakan suatu payung organisasi yang membawahi 40 milisi di Irak (Mansour \& 'Abd alJabbār, 2017). Wakil ketua PMF, Abu Mahdi al-Muhandis, turut menjadi target serangan udara AS bersama Soleimani.

Hidayatullah.com memberikan framing bahwa Soleimani merupakan arsitek Iran dalam konflik di Timur Tengah. Disebutkan juga dalam artikel berita, berdasarkan tweet seorang senator AS, Chris Murphy, yang dikutip oleh Hidayatullah.com, bahwa Soleimani merupakan sosok kedua yang paling berpengaruh di Iran dan merupakan musuh AS. Konflik di Timur Tengah tersebut antara lain adalah konflik di Suriah dan serangan roket ke Israel. Soleimani digambarkan berusaha untuk mendapatkan pengaruh dalam pemerintahan Suriah.
Framing kepada Soleimani yang digambarkan berusaha mendapatkan pengaruh dalam pemerintahan Suriah, dalam pemberitaan dijadikan alasan mengapa AS melakukan penyerangan terhadap Soleimani.

Teks berita yang kedua memberitakan tentang adanya rencana Iran untuk melakukan serangan balasan atas pembunuhan Soleimani. Informasi ini ditonjolkan melalui pernyataan dari mantan komandan IRGC, Mohsen Razaei, bahwa Iran akan memberikan pembalasan keras kepada AS. Selain itu Hidayatullah.com juga mengutip pernyataan dari pemimpin tertinggi Iran, Ayatollah Ali Khamenei, pembalasan keras menunggu pembunuh Soleimani.

Pembunuhan Soleimani menyebabkan meningkatnya ketegangan antara AS dan Iran dan merupakan tindakan yang berbahaya. Dikutip dari teks berita kedua, pemimpin DPR Amerika Serikat, Nancy Pelosi, menyatakan bahwa pembunuhan Soleimani beresiko memicu konflik lebih lanjut yang berbahaya. Juga, Pelosi menambahkan bahwa tindakan tersebut diambil tanpa adanya persetujuan dari Kongres. Selain itu, Hidayatullah.com juga menambahkan tweet dari seorang politisi AS, Adam Schiff, yang menyatakan bahwa rakyat Amerika tidak menginginkan perang dengan Iran. Dalam teks berita ini Hidayatullah.com mencoba untuk memperjelas bahwa konflik antara AS dan Iran pasca kematian Soleimani merupakan konflik yang berbahaya.

Di samping itu, Hidayatullah.com turut menonjolkan fakta bahwa konflik antara Iran dan AS akibat terbunuhnya Soleimani berdampak dalam aspek ekonomi. Dalam teks berita, terdapat pernyataan bahwa harga minyak melonjak lebih dari 4 persen pada Jumat setelah munculnya berita mengenai kematian Soleimani. Hal ini disebabkan karena adanya kekhawatiran dari pasar bahwa Iran 
akan menyerang aset-aset AS dan sekutu mereka di Timur Tengah.

Dalam teks berita ini juga terdapat deskripsi mengenai sosok Soleimani pada bagian penutup berita serta reaksi dari sekelompok warga Irak yang menyambut kematian Soleimani. Pada teks berita kedua ini terdapat framing bahwa Soleimani merupakan sosok yang memiliki peran penting dalam kegiatan terorisme di Timur Tengah. Selain itu, karena peran Soleimani yang terlibat dalam banyak kegiatan terorisme di Timur Tengah, maka Hidayatullah.com memberikan framing bahwa terdapat sekelompok orang yang bergembira atas kematian Soleimani. Hidayatullah.com (2020), menuliskan pernyataan bahwa terdapat video yang viral di Twitter yang memperlihatkan massa membawa bendera Irak sambil berlari-lali di jalanan menyambut kematian Soleimani. Pernyataan ini juga terdapat di bagian excerpt atau kutipan di awal teks berita untuk menonjolkan bahwa kematian Soleimani disambut gembira oleh sebagian rakyat Irak.

\section{Berdasarkan Eriyanto (2002),} framing dalam berita melalui proses seleksi isu yang berhubungan dengan pemilihan fakta. Dari realitas-realitas yang kompleks dan beragam, berbagai aspek akan diseleksi sebelum akhirnya ditampilkan. Dari proses ini ada bagian berita yang dimasukkan, tetapi ada juga berita yang dikeluarkan. Dalam hubungannya dengan teks berita kedua, sekelompok massa yang membawa bendera Irak sambal berlari-lari di jalanan merayakan kematian Soleimani lebih ditonjolkan daripada fakta lain. Di sisi lain, prosesi pemakaman Soleimani tidak hanya diselenggarakan di Iran, namun juga di Irak. Prosesi tersebut dihadiri oleh ribuan orang dan diselenggarakan di tiga kota di Irak, yaitu Baghdad, Najaf, dan Karbala (Ibrahim, 2020). Di sini terlihat Hidayatullah.com berusaha lebih menonjolkan sekelompok orang yang merayakan kematian Soleimani daripada ribuan orang yang menghadiri prosesi pemakaman Soleimani di Irak.

Untuk teks berita ketiga yang ditulis pada tanggal 7 Januari 2020, memberitakan tentang prosesi pemakaman Qassem Soleimani yang menelan puluhan korban jiwa. Pernyataan ini dikutip Hidayatullah.com dari kantor berita Fars yang melaporkan bahwa 40 orang meninggal dunia dan 213 orang lainnya terluka.

Peristiwa ini terjadi karena adanya insiden desak-desakan. Hidayatullah.com menonjolkan insiden desak-desakan ini dengan mendeskripsikan video yang viral di media sosial. Video tersebut menunjukkan orang-orang terbaring tak bernyawa di jalan, sementara yang lain berteriak dan berusaha membantu mereka.

Dalam teks berita ini digambarkan bahwa terdapat ratusan ribu orang berkumpul di kota Kerman, tempat Soleimani dimakamkan. Sebelumnya prosesi pengiringan jenazah Soleimani juga dilakukan di kota-kota lain di Iran seperti di Ahvaz, Mashhad, Teheran, dan Qom. Penumpukan peziarah terjadi di Kerman, karena di Kerman merupakan prosesi terakhir pengiringan jenazah Soleimani sebelum akhirnya dimakamkan. Hal ini sesuai dengan pernyataan koresponden $\mathrm{Al}$ Jazeera, Assed Beig, bahwa penumpukan peziarah ini yang menjadi salah satu penyebab terjadinya insiden desakdesakan. Insiden ini pada akhirnya menyebabkan pemakaman Soleimani ditunda.

Pada teks berita ketiga ini, seperti di teks berita kedua, terdapat framing yang menggambarkan bahwa Soleimani merupakan sosok teroris. Terdapat pernyataan di akhir teks berita bahwa Soleimani adalah pemimpin Pasukan Quds yang merupakan kelompok bersenjata Syiah yang ikut mendukung pemerintah 
rezim Bashar al-Assad yang telah membunuh puluhan ribu warga sipil Suriah sejak perang sipil pecah.

Teks berita keempat melaporkan tentang serangan Iran terhadap Amerika Serikat. Serangan ini berbentuk tembakan selusin rudal pada salah satu pangkalan militer Amerika Serikat di Irak, Ain alAsad. Serangan ini merupakan serangan pembalasan atas pembunuhan Qassem Soleimani dalam serangan udara di Baghdad, Irak.

Serangan balasan Iran kepada AS ini menimbulkan kekhawatiran dari anggota parlemen di Capitol Hill. Seperti yang dikutip dari teks berita Hidayatullah.com, salah satu politikus AS, senator Richard Blumenthal, mengungkapkan bahwa serangan tersebut cukup serius dan kekhawatiran tentang serangan tersebut harus dipublikasikan.

Hidayatullah.com menonjolkan betapa berbahayanya konflik antara Iran dan AS dengan pernyataan tambahan bahwa pihak Iran tidak hanya berencana untuk menyerang AS secara khusus, namun juga menyerang semua negara sekutu AS yang melancarkan serangan dari pangkalan militer di negara mereka kepada Iran. Selain itu, berdasarkan pernyataan resmi IRGC yang dikutip dalam teks berita keempat, bahwa serangan udara ke pangkalan militer Ain al-Asad hanyalah permulaan dari serangkaian serangan pembalasan tanpa batas waktu kapan berakhir.

Seperti dalam teks berita kedua dan ketiga, pada teks berita keempat turut memberikan framing bahwa Soleimani merupakan arsitek dari berbagai konflik yang terjadi di Timur Tengah. Pada bagian akhir teks berita keempat terdapat penjelasan mengenai peran Soleimani di Timur Tengah.
Dalam salah satu paragraf di bagian akhir teks berita, Soleimani digambarkan memiliki hubungan dengan rezim Bashar al Assad di Suriah. Hidayatullah.com menyatakan bahwa Bashar al Assad, presiden Suriah yang sedang menjabat, merupakan sosok yang keji.

Hubungan Soleimani dan Bashar al Assad ditonjolkan oleh Hidayatullah.com dalam satu paragraf. Penonjolan tersebut digambarkan dengan peran Soleimani pada perang sipil di Suriah yang berlangsung sejak tahun 2011. Hidayatullah.com memberikan framing bahwa Soleimani memimpin pembantaian warga sipil dan mujahidin di Suriah. Konflik yang menimbulkan banyak korban ini diperjelas oleh Hidayatullah.com dengan mengutip The Syrian Observatory for Human Rights yang menyatakan bahwa perang sipil di Suriah telah mengorbankan hampir 400 ribu warga sipil. Hubungan Soleimani dengan Bashar al Assad ditonjolkan dalam teks berita, bahwa Soleimani mengerahkan ribuan milisi Syiah bersenjata dan penasihat militer ke Suriah untuk melindungi pemerintah Bashar al Assad yang dalam paragraf sebelumnya digambarkan memerintah rezim secara keji.

Selain itu, Hidayatullah.com juga memberikan framing bahwa Soleimani melancarkan tindak kekerasan kepada pengunjuk rasa di Irak yang menewaskan ratusan orang. Soleimani juga dianggap berusaha menguasai pemerintahan Irak. Tindakan Soleimani tersebut dibingkai dalam teks berita ini sebagai penyebab bergejolaknya negara Irak.

Menurut Eriyanto (2002), framing dapat dipandang sebagai penempatan informasi dalam konteks yang khas sehingga isu tertentu mendapatkan porsi yang lebih menonjol daripada isu yang lain. Dalam konteks teks berita keempat, Hidayatullah.com mencoba untuk menempatkan posisi Soleimani sebagai sosok yang berperan dalam berbagai 
konflik yang terjadi di Timur Tengah. Sementara itu, pada teks berita keempat, jika melihat dari judul dan sebagian besar isi berita, pemberitaan berfokus pada tindakan pembalasan Iran kepada AS dengan menyerang pangkalan militer AS di Irak. Namun, pada bagian akhir teks berita, Hidayatullah.com menonjolkan peran dan sosok Soleimani yang turut andil dalam konflik Timur Tengah. Di dalam teks berita ini, penggambaran Soleimani sebagai sosok yang membuatkan kekacauan mencoba untuk lebih ditonjolkan daripada serangan balasan Iran kepada AS. Hal ini juga ditunjukkan pada bagian excerpt atau kutipan di awal teks berita, yang menyatakan bahwa Soleimani dan Abu Mahdi al-Muhandis dianggap sebagai arsitek kekerasan yang menewaskan ratusan pengunjuk rasa Irak dan ikut "mencengkram" kekuatan politik negara itu.

Teks berita kelima yang dianalisis memberitakan tentang pertemuan wakil Menteri Pertahanan Arab Saudi, pangeran Khalid bin Salman, dengan presiden AS, Donald Trump pada tanggal 9 Januari 2020. Dalam pertemuan tersebut dibahas tentang kerja sama dan koordinasi antara Arab Saudi dan Amerika Serikat, termasuk upaya untuk menghadapi tantangan regional dan internasional. Selain bertemu dengan presiden Trump, pangeran Khalid bin Salman juga bertemu dengan Menteri Luar Negeri AS, Mike Pompeo dan Menteri Pertahanan AS, Mark Esper. Terdapat pembahasan tentang langkah-langkah untuk mempertahankan stabilitas di regional dan kerja sama militer dalam pertemuan antara pejabat tinggi Amerika Serikat dan Arab Saudi tersebut.

Pertemuan tersebut diselenggarakan beberapa hari setelah serangan udara AS yang membunuh Soleimani. Dalam teks berita ini, Hidayatullah.com memberikan framing terhadap peran Iran di Timur Tengah dengan menyertakan salah satu tweet dari Mike Pompeo yang berbunyi, "Hubungan AS-Saudi tetap sangat penting untuk melawan perilaku merusak rezim Iran \& membawa keseimbangan di Timur Tengah". Tweet ini disertakan pula pada bagian awal teks berita atau excerpt. Dengan mengutip tweet dari Pompeo ini dan meletakkannya di bagian awal teks berita, maka Hidayatullah.com mencoba untuk menonjolkan bahwa Iran menciptakan kekacauan di Timur Tengah.

Namun dalam pertemuan dengan Pompeo, pangeran Khalid bin Salman meminta pihak AS untuk menahan diri untuk memberikan serangan lebih lanjut kepada Iran. Hal ini ditonjolkan dengan pernyataan yang dikutip dari CNN bahwa pihak Arab Saudi tidak menginginkan kekacauan di Timur Tengah. Penyebabnya adalah Arab Saudi pernah menjadi target sebelumnya dan mungkin akan menjadi target lagi.

Selain memberitakan tentang kekhawatiran Arab Saudi atas konflik antara Iran dan Amerika Serikat, dalam teks ini juga diberitakan mengenai konflik antara Irak dan Amerika Serikat. Hidayatullah.com mencoba untuk menunjukkan bahwa pembunuhan Soleimani tidak hanya berdampak pada ketegangan antara Iran dan Amerika Serikat, tetapi juga pada hubungan antara Irak dan Amerika Serikat. Pembunuhan Soleimani bersama Wakil Komandan Pasukan Mobilisasi Populer (PMF) Irak, Abu Mahdi Al-Muhandis di dekat bandara internasional Baghdad, Irak menjadi pemicu ketegangan hubungan Irak dan Amerika Serikat.

\section{PENUTUP}

\section{Simpulan}

Berdasarkan hasil analisis framing yang telah dilakukan terhadap media online Hidayatullah.com pada periode Janauri 
2020 dapat disimpulkan bahwa ditemukan 3 artikel berita yang menampilkan bingkai negatif terhadap Qassem Soleimani. Dalam 3 artikel berita tersebut, Hidayatullah.com cenderung berupaya menampilkan Soleimani sebagai sosok yang berperan dalam konflik-konflik yang terjadi di negara-negara Timur Tengah, misalnya Irak dan Suriah. Melalui isi artikel seperti pemilihan judul, peletakan dan pemilihan kutipan yang mendukung bahwa Soleimani merupakan salah satu penyebab terganggunya stabilitas di beberapa negara di Timur Tengah. Selain itu, peneliti menemukan tiga topik besar yang dibahas dalam 5 artikel berita yang menjadi data penelitian, yaitu tentang pembunuhan Soleimani di dekat bandara Internasional Baghdad, meningkatnya ketegangan hubungan antara Iran dan Amerika Serikat yang menimbulkan kekhawatiran dari berbagai pihak, dan sosok Soleimani yang dianggap sebagai penyebab konflik di Suriah dan Irak.

\section{Saran}

Peneliti menyarankan kepada pembaca berita di media agar lebih kritis dalam menyikapi berita di media, termasuk media online Hidayatullah.com. Masyarakat diharapkan memahami literasi media. Untuk penelitian selanjutnya pada pemberitaan di media online Hidayatullah.com, peneliti menyarankan untuk dapat menggunakan model framing selain Entman, misalnya model framing William Gamson dan Andre Modigliani. Selain itu, untuk penelitian selanjutnya, untuk metode penelitian dapat menggunakan teori yang berbeda seperti analisis isi dan analisis wacana.

\section{DAFTAR PUSTAKA}

Al Nahed, S. (2015). Covering Libya: A framing analysis of Al Jazeera and BBC coverage of the 2011 Libyan uprising and NATO intervention. Middle East Critique, 24(3), 251-267.
Damayanti, S., Mayangsari, I. D., \& Putra, D. K. S. (2016). Analisis framing Robert N. Entman atas pemberitaan reklamasi Teluk Jakarta di majalah Tempo. eProceedings of Management, 3(3).

Dareini, A. A. (2020). A Thick Cloud in the US-Iran Climate. Diambil dari https://studies.aljazeera.net/sites/defa ult/files/articles/documents/202002/A\%20Thick\%20Cloud\%20in\%20 the $\% 20$ US-Iran\%20Climate.pdf

Elmasry, M. (2009). Death in the Middle East: An analysis of how the New York Times and Chicago Tribune framed killings in the second Palestinian intifada. Journal of Middle East Media, 5(1), 1-46

Eriyanto. (2002). Analisis framing: konstruksi, ideologi, dan politik media. Yogyakarta: LKiS.

Ibrahim, A. (2020, 4 Januari). 'You never let us down': Thousands mourn Soleimani in Baghdad. Al Jazeera. Diambil dari https://www.aljazeera.com/news/2020/ 01/thousands-mourners-joinsoleimani-funeral-baghdad200104074845279.html

Kriyantono, R. (2014). Teknik praktis riset komunikasi. Jakarta: Prenada Media.

Margianto, J. H., \& Syaefullah, A. (2012). Media online: Pembaca, laba, dan etika. Jakarta: Aliansi Jurnalis Independen Indonesia.

Mansour, R., \& 'Abd al-Jabbār, F. (2017). The Popular Mobilization Forces and Iraq's Future (Vol. 28). Washington, DC: Carnegie Endowment for International Peace. 
Muhammad, M. H. (2011). Metode Penelitian Bahasa. Yogyakarta: Ar-Ruzz Media.

Musyaffa. (2017). Konstruksi pemberitaan media online Indonesia terhadap ISIS (analisis framing Kompas.com, Okezone.com, Tempo.co, dan Republika. co.id). (Tesis Magister, Universitas Islam Negeri Syarif Hidayatullah, Jakarta). Diambil dari http://repository.uinjkt.ac.id/dspace/ha $\underline{\text { ndle/123456789/38300 }}$

O'Neal, J. (2020). Mounting tensions in the Middle East Following U.S. Killing of High-ranking Iranian Military leader. Diambil dari http://yris.yira.org/comments/3701

Papacharissi, Z., \& de Fatima Oliveira, M. (2008). News frames terrorism: A comparative analysis of frames employed in terrorism coverage in US and UK newspapers. The international journal of press/politics, 13(1), 52-74.

Pohan, D. A. (2017). Analisis framing pemberitaan "pernyataan Basuki Tjahja Purnama (Ahok) mengenai QS. AlMaidah ayat 51" oleh Republika.co.id dan Hidayatullah.com. (Skripsi Sarjana, UIN Syarif Hidayatullah, Jakarta, Indonesia). Diambil dari http://repository.uinjkt.ac.id/dspace/han dle/123456789/40185

Rachmawati, F., Kriyantono, R., \& Antoni. (2019). Analisis framing kegiatan keislaman Joko Widodo melalui portal berita Setkab.go.id dalam menjawab isu Jokowi antiislam periode Oktober 2014-Juli 2018. CHANNEL: Jurnal Komunikasi, 7(1), 19.

Rizqiyah, K. (2016). Hidayatullah.com sebagai media dakwah mandiri (strategi manajemen redaksi dalam pelaksanaan dakwah dan daya tarik umat melalui portal berita online). (Skripsi sarjana, UIN Sunan Ampel, Surabaya, Indonesia). Diambil dari http://repository.uinjkt.ac.id/dspace/ha $\underline{\text { ndle } / 123456789 / 38300}$

Solihin, M., \& Kurnia, N. (2017). Pemaknaan konflik pabrik semen Kendeng dalam framing media berita online Kompas.com dan Suaramerdeka.com. Jurnal Ilmu Komunikasi, 15(1). 